\title{
Influence of particulate matter and meteorological conditions on multiple sclerosis relapse: a preliminary study in São Paulo, Brazil
}

\author{
Influência do material particulado e condições meteorológicas em surto de \\ esclerose múltipla: um estudo preliminar em São Paulo, Brasil

\section{Influencia de la materia particulada y condiciones meteorológicas en la} \\ esclerosis múltiple recaída: un estudio preliminar en Sao Paulo, Brasil
}

\author{
Fernanda Rodrigues DINIZ ${ }^{1}$ \\ Ana Lucia Frony MACEDO ${ }^{2}$ \\ Marina Piacenti da SILVA ${ }^{\mathbf{1 , 3}}$ \\ ${ }^{l}$ Department of Physics, Faculty of Sciences, UNESP Univ. State of São Paulo, 17033-360 Bauru-SP, Brazil \\ ${ }^{2}$ Climatempo, Meteorological Company, 04011-061, São Paulo -SP, Brazil \\ ${ }^{3}$ IPMet- UNESP Meteorological Center, Univ. State of São Paulo, 17033-360 Bauru-SP, Brazil
}

\begin{abstract}
Introduction: Multiple sclerosis (MS) is a chronic, inflammatory, and demyelinating disease of the central nervous system, which in some cases may be characterized by recurrent relapses of inflammation that cause mild to severe neurological disability. Some studies around the world have associated the increase of systemic inflammatory responses and neuro-inflammation of patients with exposure to high levels of particulate matter $\left(\mathrm{PM}_{10}\right)$ and certain conditions of temperature and humidity. Materials and methods: The objective of this study was to verify the influence of the concentration of $\mathrm{PM}_{10}$ and meteorological variables (air temperature and relative humidity) on the number of hospitalizations for MS in the city of São Paulo. Data from 2008 to 2016, which passed through descriptive statistics and inferences, were used as multiple linear regression models. Results: The models obtained indicated a positive relation $(\mathrm{p}<0.01)$ in the number of hospitalizations with the increase of $\mathrm{PM}_{10}$ and relative humidity, showing that $31.23 \%$ of hospital admissions can be explained by these variables. Conclusion: These results are important, since there are no other studies from Brazil that correlate meteorological and air quality variables with MS.

Descriptors: Air Pollution; Multiple Sclerosis; Linear Models.
\end{abstract}

\section{Resumo}

Introdução: A Esclerose Múltipla (EM) é uma doença crônica, inflamatória e desmielinizante do sistema nervoso central, que em alguns casos pode ser caracterizada por surtos recorrentes de inflamação que causam leve a grave deficiência neurológica. Alguns estudos em todo o mundo têm associado o aumento de respostas inflamatórias sistêmicas e neuroinflamação de pacientes quando expostos a altos níveis de material particulado $\left(\mathrm{MP}_{10}\right)$ e certas condições de temperatura e umidade. Material e Método: $\mathrm{O}$ objetivo deste estudo foi verificar a influência da concentração de material particulado $\left(\mathrm{MP}_{10}\right)$ e das variáveis meteorológicas (temperatura do ar e umidade relativa) sobre o número de internações por EM na cidade de São Paulo. Para isso foram utilizados dados destas no período de 2008 a 2016, os quais passaram por estatísticas descritivas e inferencias, como modelos de regressão linear múltipla. Resultados: Os modelos obtidos indicaram relação positiva ( $\mathrm{p}<0,01$ ) no número de internações com o aumento do material particulado $\mathrm{MP}_{10}$ e umidade relativa, demonstrando que 31,23\% das internações hospitalares podem ser explicadas por essas variáveis. Conclusão: Esses resultados são importantes, pois até agora, em nosso conhecimento, no Brasil não existem estudos que correlacionem as variáveis meteorológicas e de qualidade do ar com a Esclerose Múltipla.

Descritores: Poluição do Ar; Esclerose Múltipla; Modelos Lineares.

\begin{abstract}
Resumen
Introducción: La esclerosis múltiple (EM) es una enfermedad del sistema crónica, inflamatoria y desmielinizante nervioso central, que en algunos casos puede ser caracterizada mediante recaídas recurrentes de inflamación causando leve a déficit neurológico grave. Algunos estudios de todo el mundo que han asociado el aumento de la respuesta inflamatoria sistémica y los pacientes neuroinflamación cuando se expone a altos niveles de partículas $\left(\mathrm{MP}_{10}\right)$ y ciertas condiciones de temperatura y humedad. Materiales y métodos: El objetivo de este estudio fue investigar la influencia de la concentración de partículas $\left(\mathrm{MP}_{10}\right)$ y variables meteorológicas (humedad relativa del aire y temperatura) sobre el número de hospitalizaciones por MS en la ciudad de Sao Paulo. Para ello se utilizaron los datos de éstas 2008-2016, estos datos han pasado a través de las estadísticas descriptivas e inferencias, como varios modelos de regresión lineal. Resultados: Los modelos indican una relación positiva $(p<0,01)$ en el número de ingresos y el aumento de partículas $\mathrm{MP}_{10}$ y la humedad relativa, lo que demuestra que 31,23\% de los ingresos hospitalarios se puede explicar por estas variables. Conclusión: Estos resultados son importantes porque hasta ahora, a nuestro entender, en Brasil no existen estudios que correlacionan las variables meteorológicas y la calidad del aire con la esclerosis múltiple.

Descriptores: Contaminación del Aire; Esclerosis Múltiple; Modelos Lineales.
\end{abstract}

\section{INTRODUCTION}

Multiple sclerosis (MS) is a disease in which neuronal myelin is the target of an autoimmune process, characterized as an inflammatory, chronic disease of unknown etiology with consequent loss of neurological function $^{1,2}$. The more accepted pathogenic hypothesis is that MS may be the result of a particular combination of genetic predisposition and action of unknown environmental factors that, when present in the same individual, may lead to this dysfunction of the neurological system ${ }^{2,3,4}$. The involvement of the neurological system can cause the patient with MS to suffer relapses. The main symptoms are muscle weakness, lack of coordination, decreased unilateral visual acuity, double vision, dizziness, and sphincter dysfunction, among others ${ }^{5}$. Hospital admissions for MS typically occur because it relapses in patients, involving a new symptom or worsening of an old symptom for more than a day or several days 6 .

Not having a known and well-defined etiology, MS is investigated worldwide. Studies show that there are possible relationships between air pollution and hospital admissions for MS relapses, because particulate materials present in the atmosphere can increase the systemic 
inflammatory response and neuro-inflammation ${ }^{3,7,8}$. Among the particulate pollutants, particulate matter $\left(\mathrm{PM}_{10}\right)$ is a pollutant classified as inhalable particles considered harmful to human health because they can be deposited in the upper respiratory tract ${ }^{9}$. Besides $\mathrm{PM}_{10}$, meteorological variables such as relative air humidity and temperature have also been considered possible factors contributing to relapses ${ }^{10}$.

To the best of our knowledge, there are no studies associating air pollution and meteorological factors with the occurrence of relapses of MS in Brazil. Therefore, the aim of this study was to evaluate the influence of meteorological parameters and $\mathrm{PM}_{10}$ concentration on hospitalizations due to MS in São Paulo, Brazil, from January 2008 to March 2016.

\section{MATERIAL AND METHOD}

\section{- Meteorological data}

The data used in this study refer to the city of São Paulo from January 2008 to March 2016. The meteorological variables are reanalyzed from NCEP/NCAR and were provided by the Climatempo ${ }^{\circledR}$ Company. Meteorological data correspond to the air temperature and relative humidity monthly averages. The monthly averages data of pollutant $\mathrm{PM}_{10}$ were obtained from air quality system data of the Environmental São Paulo State Company (QUALAR-CETESB).

\section{$\circ$ Hospital admissions data}

Monthly data of hospital admissions for MS were obtained from the online system of the computer department of the Unified Health System in Brazil (DATASUS). The data available in this system involve the number of admissions by city, age, and gender. Although studies on the impact of pollution on population health recommend that daily values of meteorological variables should be used and that hospital admissions should be divided by age group ${ }^{11}$, in this work the average monthly admissions were used, since MS has low prevalence in Brazil, with 15 cases per 100,000 inhabitants ${ }^{12}$.

\section{$\circ$ Statistical analysis}

Descriptive analyses were performed of all variables in the study. The exponential smoothing method of HoltWinters was used to smooth and eliminate any noise of the time series ${ }^{13}$. After the Kolmogorov-Smirnov test indicated normal distribution of data, the variables $\mathrm{PM}_{10}$, relative humidity, air temperature, and hospital admissions due to MS were correlated using Pearson's model ${ }^{14,15}$.

Although many studies that correlate air pollution and meteorological variables with diseases use the Poisson family of generalized linear models (MLG), in this study we used multiple linear regression ${ }^{3,16,17}$. This model was chosen because the variables have a normal distribution and, according to the residue analysis, the model was adequate for our data ${ }^{11,13,17}$. The objective of regression analysis is to measure the relation between an answer variable $(Y)$ and a set of independent explanatory variables $(X 1, X 2, \ldots)$, as shown in equation $1^{18}$. In this equation, $\beta^{\prime}$ s are the coefficients of regression, $\rho$ is the number of explanatory variables, and $\varepsilon$ is the residue.

$Y=\beta_{0}+\beta_{1} X_{1}+\ldots+\beta_{\rho} X_{\rho}+\varepsilon$

In the multiple linear regression model employed, the number of hospital admissions for MS was the dependent variable, and the explanatory variables were $\mathrm{PM}_{10}$ concentration, air temperature, and relative humidity. For the inclusion of variables in the model, we used the stepwise method. The stepwise model starts by inserting the independent variable that has the highest correlation with the response variable, and the criterion to add or remove a variable at any stage was expressed in terms of the partial $\mathrm{F}$ test. The value of $\alpha$ was 0.05 for input and 0.1 foroutput $^{19}$. The statistical software used were SPSS version 13.0, Minitab 17, and Microsoft Office Excel 2007.

\section{RESULTS}

\section{○ Descriptive statistics}

Table 1 shows the characteristics of hospitalizations in the period according to the patients' age, gender, year, and month of hospitalization. The year 2008 had the most hospital admissions, followed by 2009 , and the months with the highest incidence of hospitalizations were March and October.

\begin{tabular}{cc}
$\begin{array}{c}\text { Table 1. Distribution of cases of MS by sex, age group, year, and } \\
\text { month of hospital admission from } 2008 \text { to } 2016 \text { in São Paulo }\end{array}$ \\
\hline Variables & $\begin{array}{c}\text { Number of admissions } \\
n=1,282(100 \%)\end{array}$ \\
\hline Gender & $945(73.7 \%)$ \\
Female & $337(26.3 \%)$ \\
Male & \\
Age (years) & $434(33.9 \%)$ \\
$\leq 30$ years & $666(51.9 \%)$ \\
$30-50$ years & $182(14.2 \%)$ \\
$\geq 50$ years & \\
Year of admission & \\
2008 & $220(17.2 \%)$ \\
2009 & $216(16.8 \%)$ \\
2010 & $163(12.7 \%)$ \\
2011 & $190(14.2 \%)$ \\
2012 & $152(11.9 \%)$ \\
2013 & $105(8.2 \%)$ \\
2014 & $122(9.5 \%)$ \\
2015 & $86(6.7 \%)$ \\
2016 & $28(2.2 \%)$ \\
& \\
Month of admission & \\
Jan & $98(7.6 \%)$ \\
Feb & $116(9.0 \%)$ \\
Mar & $133(10.4 \%)$ \\
Apr & $97(7.6 \%)$ \\
May & $91(7.1 \%)$ \\
Jun & $87(6.8 \%)$ \\
Jul & $112(8.7 \%)$ \\
Aug & $115(9.0 \%)$ \\
Sep & $92(7.2 \%)$ \\
Oct & $123(9.6 \%)$ \\
Nov & $116(9.0 \%)$ \\
Dec & $102(8.0 \%)$ \\
& \\
\hline & \\
\hline & \\
\hline & \\
\hline &
\end{tabular}

It is observed in Table 1 that the number of hospital admissions for MS females was $73.7 \%$ of the total, far greater compared to men $(26.3 \%)$, and the same way that the number of admissions is higher among people aged between 30 and 50 years. These results are in agreement with other epidemiological studies worldwide, which have shown that the prevalence of MS is higher in women between 20 and 40 years old ${ }^{1,2,20}$.

Figure 1 shows boxplots of meteorological variables, pollutant $\mathrm{PM}_{10}$, and number of hospital admissions for MS in São Paulo by month (January to December).It is observed in Figure 1 that the meteorological variables present some seasonality, as expected, while the number of hospital admissions in the period presented great dispersion. Regarding the seasonal nature of variables throughout the year, the temperature and humidity are higher in summer (Dec-Feb) and lower in the winter (June-Aug). Additionally, the $\mathrm{PM}_{10}$ shows higher concentrations in winter, probably due to higher occurrences of thermal inversion in São Paulo in this season ${ }^{21}$.

To evaluate the trend and seasonality of the variables, the time series were decomposed (Figure 2). 
In Figure 2, the bars at the right-hand side are in the same range in user coordinates and indicate the relevance of each component to the series: relevance is inversely proportional to the size of the bar.

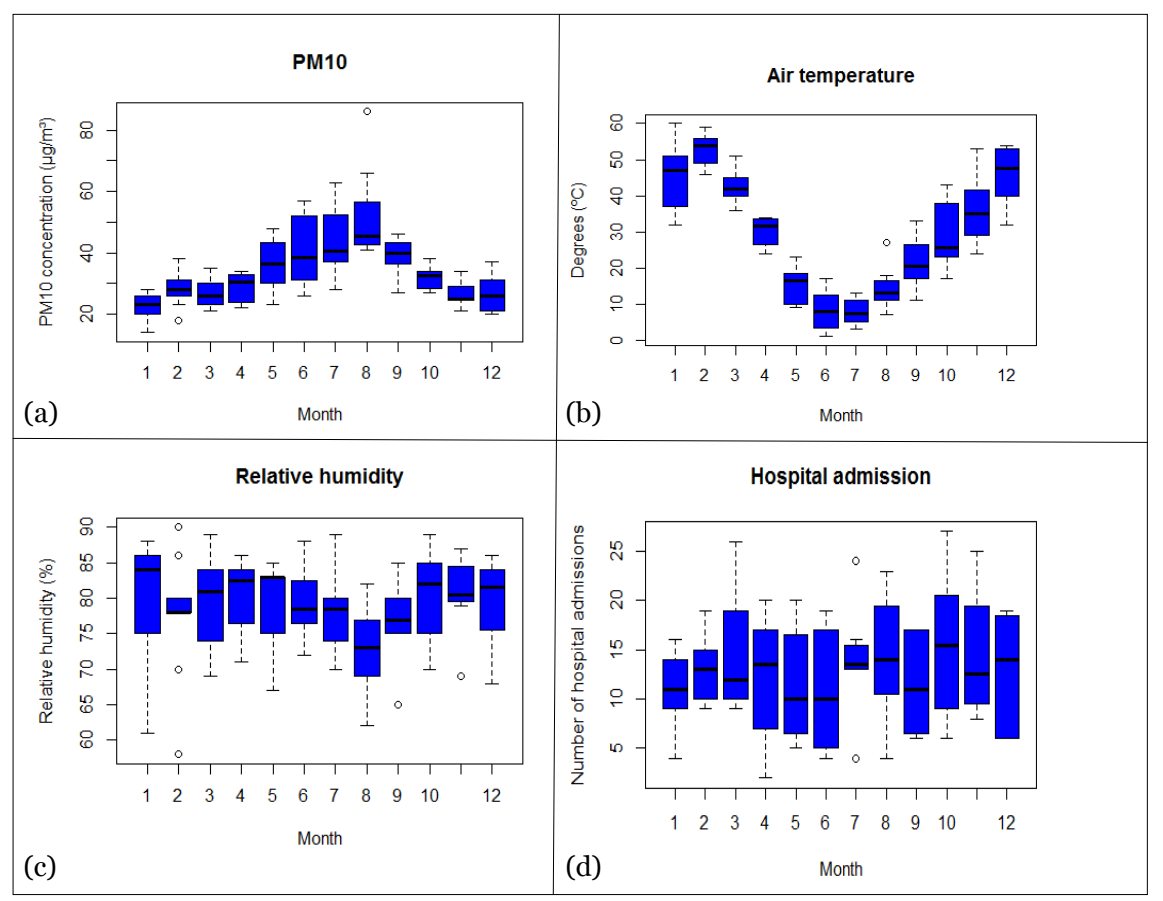

Figure 1: Temporal series of $\mathrm{PM}_{10}$ concentration, air temperature, relative humidity, and hospitalizations for MS.
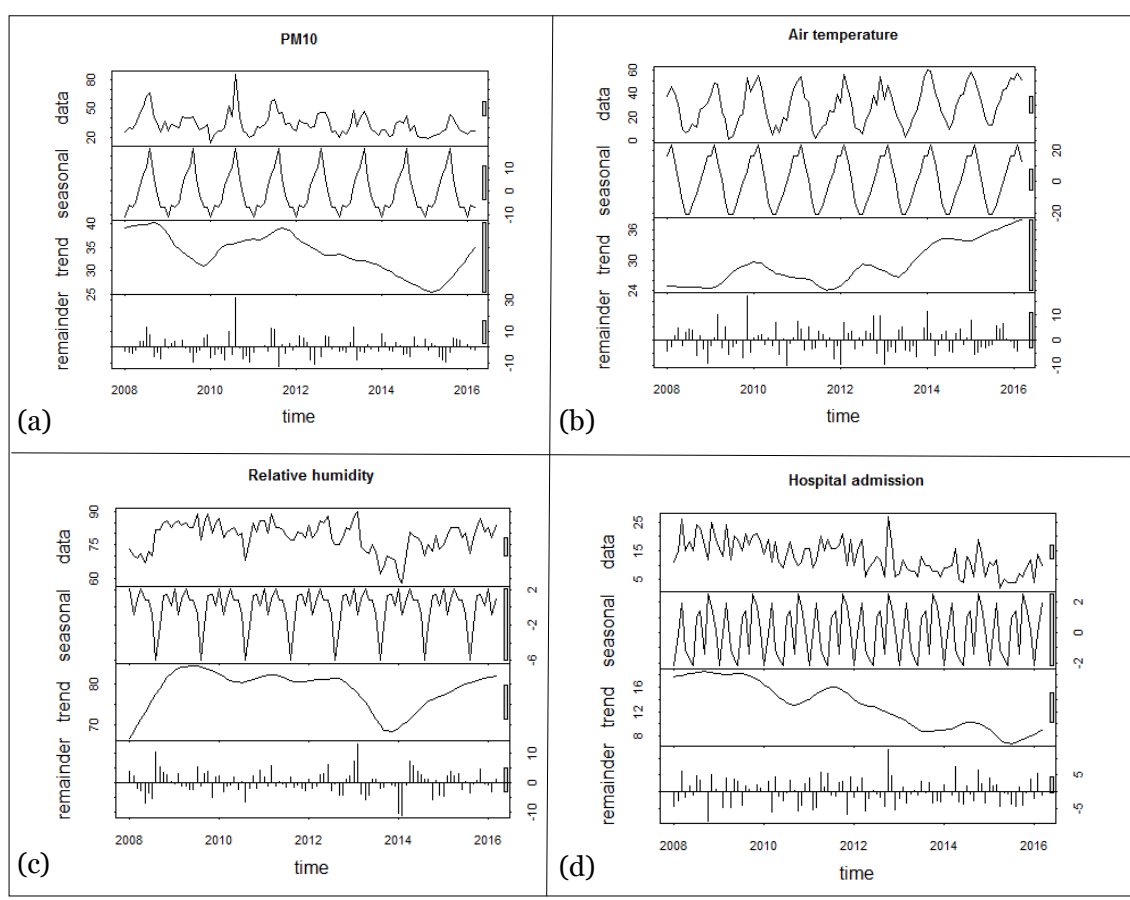

Figure 2: Decomposition of temporal series of $\mathrm{PM}_{10}$ concentration, air temperature, relative humidity, and hospitalizations for MS

Figure 2 demonstrates that $\mathrm{PM}_{10}$ concentration has shown a declining trend, probably due to the Brazilian law in 2008 requiring the use of catalytic converters in vehicles, reducing the emission of $\mathrm{PM}_{10}$ in the atmosphere ${ }^{22}$. Air temperature has a positive trend. The relative humidity has one period with values below average, justified by the fact that the years 2013/2014 were the driest registered since 1995 in São Paulo ${ }^{23}$. It is observed that hospital admissions have a negative tendency in the studied period, just as the $\mathrm{PM}_{10}$. The seasonal component appears in all series; however, as expected, this component is more relevant to explain the temperature behavior. The remainder component (irregularities) is quite relevant in all series.

There are no studies that report the cause of the decrease in hospitalizations; however, since hospitalizations and $\mathrm{PM}_{10}$ have the same trend in the study period, it can be inferred that these two variables are related in some way. To investigate a possible relation between them, Table 2 presents the results obtained from the Pearson correlation test among the meteorological variables (Temp. $=$ air temperature; Humid.= relative humidity), $\mathrm{PM}_{10}$, and the number of hospital admissions (total, by age and gender).
Table 2. Coeficients of Pearson correlation test

\begin{tabular}{|c|c|c|c|c|c|c|c|c|}
\hline & $\mathrm{PM}_{10}$ & Temp. & Humid. & Total & $\begin{array}{c}\leq 30 \\
\text { years }\end{array}$ & $\begin{array}{l}30-50 \\
\text { years }\end{array}$ & $\begin{array}{l}\geq 50 \\
\text { anos }\end{array}$ & Female \\
\hline Temp. & $\mid-0.833^{\star *}$ & & & & & & & \\
\hline Humid. & -0.113 & -0.016 & & & & & & \\
\hline Total & $0.513^{\star \star}$ & $-0.440^{\star *}$ & 0.163 & & & & & \\
\hline $\begin{array}{c}\leq 30 \\
\text { years }\end{array}$ & $0.521^{\star \star}$ & $-0.463^{\star \star}$ & -0.155 & $0.723^{\star \star}$ & & & & \\
\hline $\begin{array}{l}30-50 \\
\text { years }\end{array}$ & $0.268^{\star \star}$ & $-237^{\star}$ & $0.283^{\star \star}$ & $0.869^{\star \star}$ & $0.388^{\star \star}$ & & & \\
\hline $\begin{array}{c}\geq 50 \\
\text { years }\end{array}$ & 0.184 & -0.146 & $0.265^{\star}$ & $0.535^{\star \star}$ & $0.213^{*}$ & $0.335^{\star}$ & & \\
\hline Female & $0.477^{\star \star}$ & $-0.405^{\star \star}$ & 0.042 & $0.906^{\star \star}$ & $0.753^{\star \star}$ & $0.732^{\star \star}$ & $0.514^{\star \star}$ & \\
\hline Male & $0.199^{*}$ & -0.188 & $0.288^{\star \star}$ & $0.676^{\star \star}$ & $0.358^{\star \star}$ & $0.698^{\star \star}$ & $0.378^{\star \star}$ & $0.334^{\star \star}$ \\
\hline
\end{tabular}

* Correlation is significant at the 0.05 level

** Correlation is significant at the 0.01 level

The correlations among the concentration of $\mathrm{PM}_{10}$, the total number of hospital admissions, and almost all subgroups (age and gender) were positive, with $\mathrm{p}<0.01$, indicating that the higher the concentration of $\mathrm{PM}_{10}$, the higher the number of hospitalizations. Regarding the meteorological variables, the air temperature showed a negative correlation with hospitalizations and the relative humidity a positive correlation with admissions of patients between 30 and 50 years and of male gender. These results agree with others studies, such as that of Angelici et al. ${ }^{16}$, which demonstrated a positive relation between $\mathrm{PM}_{10}$ and MS admissions in Lombardy, Italy, and that of Gregory et al. $^{3}$, which showed a positive relation between $\mathrm{PM}_{10}$ and female patient admissions.

\section{$\circ$ Adjustments of the multiple linear regression model with the stepwise method}

Before the development of multiple linear regression, residual analysis was performed to verify the adjustment of hospitalization data and $\mathrm{PM}_{10}$ to the model, since residuals should follow a normal distribution for the model ${ }^{11,17,24}$. The independent temperature and humidity variables were also added to improve predictability. Even if the main interest is in the effect of $\mathrm{PM}_{10}$ on hospitalizations for $\mathrm{MS}$, it is advisable to include the other variables capable of affecting hospitalizations ${ }^{24}$. For the multiple linear regression models, the variables were the total number of hospitalizations and hospitalizations by age group $(\leq 30$ years, between 30 and 50 years, and $\geq 50$ years) and by gender (female and male). Figure $3 \mathrm{a}$ shows the probability of normality of fit errors. The closer the residuals are distributed, the better the model fits the data. As shown in Figure 3a, all data are well adjusted to the models, since the residuals have normal distribution.

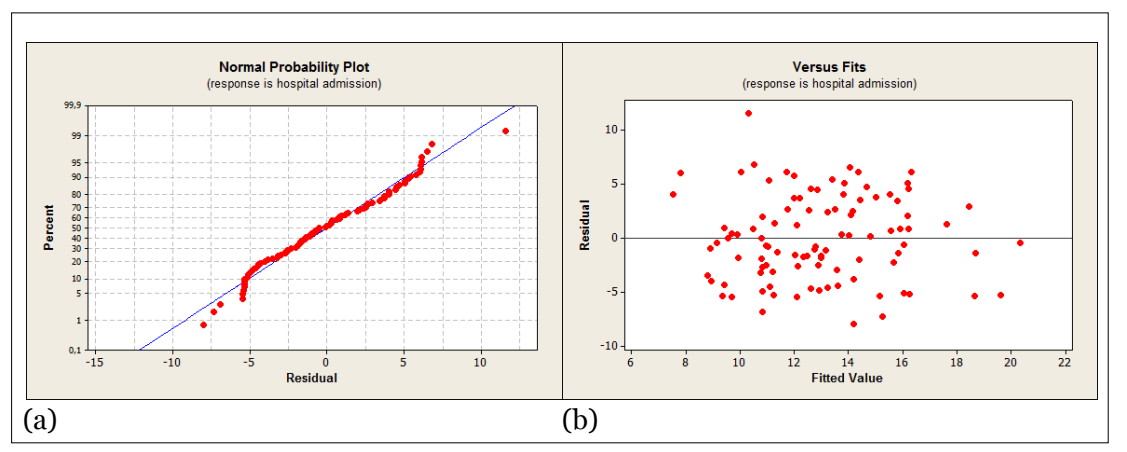

Figure 3: a) Normal probability plot to general admission; b) Residual versus fitted value to general admission

Figure $3 \mathrm{~b}$ shows residuals as a function of adjusted values. Residuals are distributed randomly around the zero mean, with no specific pattern, which justifies that the multiple linear regression models are adequate to the data $^{17,25}$ 


\section{○ Regression models}

Table 3 shows the results of the six multiple linear regression models, in which $\mathrm{R}^{2}$ indicates the coefficient of determination of each model, the coefficients $\beta$ indicate the relation of the independent variables with the responses variables, S.E is the standard error of $\beta$, the T-Value is the value of the Student's test, $p$ is the level of significance, and VIF is the inflation of variance, which measures the collinearity of the independent variables. In this case, since VIF is equal to 1 , the independent variables are not correlated.

Table 3. Results of the multiple linear regression models

\begin{tabular}{l|c|c|c|c|c|c}
\hline \multicolumn{1}{c|}{ Models } & Term & $\beta$ & $\mathrm{S} . \mathrm{E}$ & $\mathrm{T}$ - Value & $\mathrm{P}$ & $\mathrm{VIF}$ \\
\hline 1- Admission total & Constant & -9.41 & 5.30 & -1.78 & 0.08 & \\
$\mathrm{R}^{2}=31.23 \%$ & $\mathrm{PM}_{10}$ & 0.28 & 0.04 & 6.32 & 0.00 & 1.01 \\
& Humidity & 0.16 & 0.06 & 2.63 & 0.01 & 1.01 \\
\hline 2- Female admissions & Constant & 2.18 & 1.42 & 1.53 & 0.13 & \\
$\mathrm{R}^{2}=22.7 \%$ & $\mathrm{PM}_{10}$ & 0.21 & 0.04 & 5.35 & 0.00 & 1.00 \\
\hline - Male admissions & Constant & -5.68 & 2.43 & -2.34 & 0.02 & \\
$\mathrm{R}^{2}=13.76 \%$ & $\mathrm{PM}_{10}$ & 0.05 & 0.02 & 2.46 & 0.02 & 1.01 \\
& Humidity & 0.09 & 0.03 & 3.30 & 0.00 & 1.01 \\
\hline 4 - Admissions $<30$ & & & & & & \\
years & Constant & -0.61 & 0.86 & -0.71 & 0.48 & \\
$\mathrm{R}^{2}=27.15 \%$ & $\mathrm{PM}_{10}$ & 0.14 & 0.02 & 6.01 & 0.00 & 1.00 \\
\hline $5-$ Admissions 30-50 & & & & & & \\
years & Constant & -7.37 & 3.42 & -2.16 & 0.03 & \\
$\mathrm{R}^{2}=17.88 \%$ & $\mathrm{PM}_{10}$ & 0.10 & 0.03 & 3.40 & 0.00 & 1.01 \\
\hline 6 - Admissions $>50$ & Humidity & 0.14 & 0.04 & 3.42 & 0.00 & 1.01 \\
years & Constant & -3.78 & 1.64 & -2.31 & 0,02 & \\
$\mathrm{R}^{2}=11.71 \%$ & $\mathrm{PM}_{10}$ & 0.03 & 0.01 & 2.25 & 0,03 & 1.01 \\
& Humidity & 0.06 & 0.02 & 3.01 & 0.00 & 1.01 \\
\hline
\end{tabular}

Results demonstrate that all models indicated a positive relation in the number of hospitalizations and $\mathrm{PM}_{10}$ concentration, as shown by the $\beta$ coefficients in Table 3 . In addition to the $\mathrm{PM}_{10}$, most of the models showed a positive relationship of hospitalizations with relative air humidity. Air temperature was removed from the models because it did not have a significant representation $(p>0.05)$. This probably can be explained by the fact that high relative humidity and high particulate pollution occur in opposite temperature conditions (summer and winter, respectively). The best model was considered as a response to the number of total admissions, which obtained a higher coefficient of determination $\left(\mathrm{R}^{2}\right)$, indicating that $31.23 \%$ of the number of hospitalizations can be explained by $\mathrm{PM}_{10}$ and relative humidity.

\section{DISCUSSION}

$\mathrm{PM}_{10}$ is one of the most harmful pollutants to human health, and many studies try to understand its effects on health, especially in cases of respiratory and cardiovascular diseases $^{26-28}$. In addition to respiratory and cardiovascular diseases, recent studies have shown that air pollution may have an influence on neurodegenerative diseases, such as Parkinson's disease, Alzheimer's, and $\mathrm{MS}^{3,16,29}$. Among the various pollutants, particulate materials and heavy metals are prominent in the impact of neurodegenerative diseases, due to the fact that these pollutants contribute to the neuroinflammatory response $\mathrm{s}^{3,5}$.

MS, the focus of this study, is a disease of unknown etiology, making studies even more difficult and complex but necessary to discover the origin of the disease. Not only the origin of MS but also the progression of the disease is a mystery. Patients with a recurrent type of MS are most affected by relapses of MS, which mostly cause hospital admissions and sometimes new neurological lesions ${ }^{2,6}$.

In this study, we investigated MS hospitalizations in the city of São Paulo over a period of eight years (20082016). During this period, there were a total of 1,282 hospitalizations, in which the majority included women between 30 and 50 years of age. This study was limited only to hospitalizations by the Unified Health System (UHS), which means that it does not represent all MS hospitalizations in the city of São Paulo, which in many cases occur in private hospitals.

Despite this limitation, we obtained good results from the relationships between MS hospitalizations and $\mathrm{PM}_{10}$ for the city of São Paulo. For all age groups and genres, concentrations of $\mathrm{PM}_{10}$ were shown to contribute to the increase in hospitalizations ( $p<0.01$ ). Our study is in agreement with the results obtained by Angelici et al. ${ }^{16}$ and Gregory et al. ${ }^{3}$ which showed a relationship between the increase in $\mathrm{PM}_{10}$ concentrations and the increase in admissions in Lombardy, Italy, and Tehran, Iran, respectively. In addition to $\mathrm{PM}_{10}$, our study also showed a positive relation $(\mathrm{p}<0.01)$ of hospitalizations with relative air humidity. In the study of Salvi et al. ${ }^{10}$ the authors also pointed out the relationships between the seasonality of MS hospitalizations and the seasonality of relative air humidity in Italy. Other studies show that high relative humidity causes increased fatigue in patients with $\mathrm{MS}^{30,31}$.

Our study focused only on the pollutant $\mathrm{PM}_{10}$, due to the fact that there is more literature on MS and this pollutant, mainly and only from other countries. However, we should not rule out the possibility that other pollutants may also contribute significantly to the occurrence of MS relapses, as well as the contribution of meteorological variables, since air pollution always acts in conjunction with atmospheric conditions, which should not be neglected.

\section{CONCLUSION}

Our results showed that the higher the relative humidity and $\mathrm{PM}_{10}$ concentrations, the greater the number of hospitalizations for MS. The models indicated a higher $\mathrm{PM}_{10}$ ratio with female hospitalizations of the age group below 30 years. The results obtained in this work confirm for the city of São Paulo the hypothesis that air pollution, as well as some atmospheric conditions, may play an important role in the occurrence of MS relapses. These results are important, since up to now in Brazil there are no studies concerning meteorological or air quality variables with such disease. In addition, they may open new viewpoints to investigate the pathogenic mechanisms of MS.

\section{ACKNOWLEDGMENTS}

We thank the funding agency FAPESP (Process 2015/18613-4) for supporting this research, CETESB for supplying the air quality data, and the company Climatempo for supplying the meteorological variables.

\section{REFERENCES}

1. Baggio BF, Teles RA, Renosto A, Alvarenga FC. Peerfil epidemiológico de indivíduos com Esclerose Múltipla de uma associação de referência. Rev Neurocienc. 2011; 19(3):458-61.

2. Moreira MA, Felipe E, Mendes MF, Tilbery CP. Multiple sclerosis: a descriptive study of its clinical forms in 302 cases. Arq Neuro-Psychiatr. 2000; 58(2B):460-6.

3. Gregory AC 2nd, Shendell DG, Okosun IS, Gieseker KE. Multiple Sclerosis disease distribution and potential impact of environmental air pollutants in Georgia. Sci Total Environ. 2008, 396(1):42-51.

4. Wang Z, Sadovnick AD, Traboulsee AL, Ross JP, Bernales CQ, Encarnacion $M$ et al.Nuclear receptor 
NR1H3 in familial multiple sclerosis. Neuron. 2016; 90(5):948-54.

5. Oliveira EML, Souza NA. Esclerose Múltipla. Rev Neurociências. 1998; 6 (3):114-8.

6. Finkelsztejn A. Tratamento do surto de esclerose múltipla em Hospital-Dia: estudo de custo-minimização [dissertação]. Porto Alegre: Universidade Federal do Rio Grande do Sul; 2007.

7. Heydarpour P, Amini H, Khoshkish S, Seidkhani H, Sahraian MA, Yunesian M. Potential Impact of Air Pollution on Multiple Sclerosis in Tehran, Iran. Neuroepidemiology. 2014; 43(3-4):233-8.

8. Vojinovic S, Savic D, Lukic S, Savic L, Vojinovic J. Disease relapses in multiple sclerosis can be influenced by air pollution and climate seasonal conditions. Vojnosanitetski Pregled. 2015; 72(1):44-9.

9. CETESB. Air quality in the state of São Paulo 2012. Environmental Commitment of the State of São Paulo, 2013.

10. Salvi F, Bartolomei I, Smolensky MH, Lorusso A, Barbarossa E, Malagoni AM et al. A seasonal periodicity in relapses of multiple sclerosis? A singlecenter, population-based, preliminary study conducted in Bologna, Italy. BMC Neurol. 2010; 10:105.

11. Tadano YS, Ugaya CML, Franco AT. Ressão de Poisson: metodologia para avaliação do impacto da poluição atmosférica da saúde populacional. Ambiente \& Sociedade. 2009; 12(2):241-55.

12. Brasil. Ministério da Saúde. Portaria nº 493 de 23 de setembro de 2010

13. Coelho-Barros EA, Simões PA, Achcar JA, Martinez EZ, Shimano AC. Methods of estimation in multiple linear regression: application to clinical data. Rev Colomb Stad. 2008; 31(1):111-29.

14. Lopes MM, Castelo Branco VTF, Soares JB. Utilização dos testes estatísticos de Kolmogorov-Smirnov e Shapiro-Wilk para verificação da normalidade para materiais de pavimentação. Transportes. 2013; 21(1):59-66.

15. Figueiredo Filho DB, Rocha EC, Silva Junior JA, Paranhos R, Neves JAB, Silva MB. Desvendando os mistérios do coeficiente de correlação de Pearson: o retorno. Leviathan. 2014; 8:66-95.

16. Angelici L, Piola M, Cavalleri T, Randi G, Cortini F, Bergamaschi R, et al. Effects of particulate matter exposure on multiple sclerosis hospital admission in Lombardy region, Italy. Environ Res. 2016; 145:68-73.

17. Larazzi AR. Comparison of statistical techniques to analyze the relationship between respiratory diseases and concentrations of air pollutants. Ciência Natura. 2013; 35(1):98-105.

18. Prado FA, Berveglieri A, Tachibana VM, Imai NN. Aplicação e análise de modelos de regressão clássica e espacial para os distritos da cidade de São Paulo. In: III Simpósio Brasileiro de Ciências Geodésicas e Tecnologias da Geoinformação, 2010, Recife. Anais do III SIMGEO. Recife: Universidade Federal de Pernambuco, 2010.

19. Abbad G, Torres CV. Regressão múltipla stepwise e hierárquica em Psicologia Organizacional: aplicações, problemas e soluções. Estud psicol. 2002; 7(spe):19-29.

20. Ferreira MLB, Machado MIM, Vilela ML, Guedes MJ, Ataíde Jr L, Santos S et al. Epidemiology of 118 cases of multiple sclerosis with segments of 15 years in the reference center of the hospital of the restoration of Pernambuco. Arq Neuro-Psiquiatr. 2004; 62(4):1027-32.
21. Botelho C, Correia AL, Silva AMC, Macedo AG, Silva COS. Fatores ambientais e hospitalizações em crianças menores de 5 anos com infecção respiratória aguda. Cad Saúde Pública. 2003;19(6):1771-80.

22. Brasil. Instituto Nacional de Metrologia, Estandardização e Qualidade Industrial (INMETRO). Portaria ${ }^{\circ} 346$ de 3 de outubro de 2008.

23. Instituto de Astronomia, Geofísica e Ciências Atmosféricas. Boletim Climatológico Anual da Estação Meteorológica do IAG/USP; 2014, v.17.

24. Tadano YS. Análise do impacto de MP10 na saúde populacional: estudo de caso em Araucária, PR. Curitiba [dissertação]. Curitiba: Universidade Tecnológica Federal do Paraná; 2007.

25. Hair JF, Black WC, Babin BJ, Anderson RE, Tatham RL. Multivariate data analysis. $6^{\text {th }}$ ed, Upper Saddle River, NJ: Pearson Prentice Hall; 2006.

26. Bernstein JA, Alexis N, Barnes C, Bernstein IL, Nel A, Peden D et al. Health effects of air pollution. J Allergy Clin Immunol. 2004; 114(5):1116-23.

27. Kampa M, Castanas E. Human health effects of air pollution. Environ Pollut. 2008;151(2):362-7.

28. Silva AR, West JJ, Zhang Y, Anenberg SC, Lamarque JF, Shindell DT et al. Global premature mortality due to anthropogenic outdoor air pollution and the contribution of past climate change. Environ Res Lett. 2013; 8:034005

29. De Toledo G, Nardocci AC. Traffic related air pollution and population health: a review about São Paulo (SP), Brazil. Rev Bras Epidemiol. 2011; 14(3):445-54.

30. Andrade VS, Silva MO. Qualidade de vida e desempenho ocupacional de indivíduos com esclerose múltipla. Acta Fisiatr. 2015, 22(3):135-40.

31. Papaléo RM, Teixeira MJ, Brioschi ML. Infrared thermography to evaluate pain in a multiple sclerosis patient. Case report. Rev Dor. 2016; 17(3):232-5.

\section{CONFLICTS OF INTERESTS}

The authors declare no conflicts of interests

\section{CORRESPONDING AUTHOR}

Marina Piacenti da Silva

marinapsilva@fc.unesp.br

Received 05/06/2017 Accepted 08/07/2017 